\title{
XYLANASE PRODUCTION FROM LOCAL BACTERIAL ISOLATE
}

\author{
R. S. K. Al-Badran \\ Researcher
}

Dept. of Biology,

Coll. of Education for Purs Science.

University of Thi-Qar.

ra1973ed@gmail.com

\section{E. I. Al-Shamary}

Assit. Prof

Dept. of Food Sci,

Coll.of Agricultural Engeneering Sciences.

University of Baghdad.

Elhamfadhil@yahoo.com

\section{ABSTRACT}

Seventeen local isolates of Bacillus were isolated from soil to produce extracellular xylanase under submerged fermentation process by using xylan as carbon sole source. All isolates were subjected to quantitative scanning to select the most efficient one. The highest activity of xylanase $(2680 \mathrm{u} / \mathrm{ml})$ was obtained from isolate Bacillus sp RS1. The isolate identified by 16SrRNA gene sequence of Bacillus subtilis ( accuracy of 99\%)which was matched with sequence of Bacillus subtilis VBN25 that recorded in Genebank under the Accession Number of MG027675.1.Extracted xylan from agricultural waste by acidic method(papyrus, sun flower stalks, Ibaa Wheat type, Furat wheat type and Abo Ghraib wheat type)were used as the substrate for xylanase production from Bacillus. The results showed that the papyrus gave the highest amount of xylan $(187.6 \mu \mathrm{g} / \mathrm{ml})$ as compared with that of the sun flower stalks, Ibaa Wheat type, Furat wheat type and Abo Ghraib wheat type $(161.3,161.6,157.6,157.2) \mu \mathrm{g} / \mathrm{ml}$ respectively. The results indicated that the highest xylanase activity was $2800 \mathrm{u} / \mathrm{ml}$ produced by Bacillus subtilus when Papyrus xylan was used.

Keywords: Bacillus subtilis, 16S rRNA , Xylan hydrolyzing enzymes, hemicelluloses. Part of ph.D. dissertation of the first author

البلران والشمري

767-759:(3)50:2019- مجلة العلوم الزراعية العراقية انتاج الزايلينيز من عزلة بكتريا محلية

$$
\begin{aligned}
& \text { الهام اسماعيل الثمري } \\
& \text { استاذ مساعد } \\
& \text { قسم علوم الاغذية/ كلية علوم الهندسة الزراعية } \\
& \text { جامعة بغداد }
\end{aligned}
$$

$$
\begin{aligned}
& \text { رائد سعيد خضير البدران } \\
& \text { باحث } \\
& \text { قسم علوم الحياة/ كلية التربية للعلوم الصرفة } \\
& \text { جامعة ذي قار }
\end{aligned}
$$

المستخلص

تم الحصول على سبعة عشر عزلة محلية لبكتريا Bacillus منتجة لانزيم الزيلنيز Xylanase باستعمال نظام تخمرات المزارع المغمورة بأستعمال الزايلان Xylan مصدرا وحيدا للكاربون، تم العصول عليها من التربة. خضعت جميع العزلات للغربلة

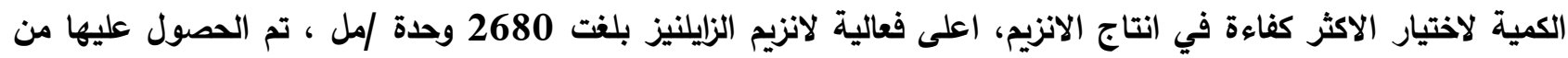

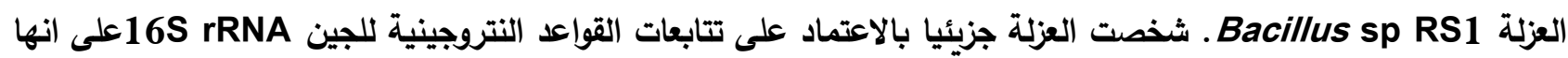
Bacillus subtilis وبنسبة تطابق 99\% Bacillus subtilus VBN25 في بنك الجينات NCBI بالرقم MG027675.1. استعمل الزايلان المستخلص من الفضلات الزراعية(البردي وسيقان زهرة الثمس والحنطة اصناف اباء وفرات وابو غربب) .(كلت النتائج ان اعلى نسبة من الزايلان تم الحصول عليها من من بن البردي (187.6 M g/ml) بالمقارنة مع سيقان زهرة الثمس والحنطة اصناف (اباء وفرات وابو غريب) حيث بلغت كمية الزايلان(161.3, 161.6, 157.6, 157.2) مايكروغرام/مل على التوالي. اكلت النتائج ان اعلى فعالية لانزيم الزايلنيز تم الحصول عليها من زايلان القصب حيث بلغت 2800 وحدة/مل باستعمال بكتربا Bacillus subtilis .

الكلمات المفتاحية: الانزيمات المحللة للزايلان، الهيميسيليلوز Bacillus subtilis،16S rRNA، بحث مستل من اطروحة دكتوراه للباحث الاول 


\section{INTRODUCTION}

Many bacterial genera including Bacillus, Cellulomonas, Clostridium, Rumminococcus, Acetivibrio, Bacteriodes, and Alteromonas can produce xylanas (17).Bacillus subtilis is nonpathogenic and nontoxigenic bacterium that has been used a source of enzymes (19). Xylanase (E.C 3.2.1.8) is a type of hydrolytic enzyme, degrades $\beta-1,4$ xylan, to produce xylose and xylooligosaccharides like xylobiose, Xylan is substrate of Xylanase, renewable organic materials and a major component of hemicellulose in plant (9),(12). Biodegradation of xylan, is a complex process that requires action of several enzymes, among which xylanase $(1,4-\beta-D-x y l a n$, EC 3.2.1.8) play a key role and $\beta$-xylosidase, $\alpha$ glucuronidase, furanosidase, $\dot{\alpha}$-arabinose and esterase (13), (16). Xylanase has many applications in the food, feed, pulp and paper industry because of its bleach boosting properties, improvement of nutritional properties of cereal diets in poultry, improvement of bakery products, clarification of fruit juice and biofuel (1),(11). The aim of this study is to get Bacillus isolate from local sources which produce a large amounts of xylanase enzyme by using agricultural waste.

\section{MATERIALS AND METHODS}

\section{Bacterial isolates sources}

The sample of Bacterial isolates were collected at depth of $5-7 \mathrm{~cm}$ from different zones of Baghdad university soils. The samples kept in sterile plastic back until time for use.

\section{Culture media}

Isolate media: The isolate media was prepared according to (17). Xylan $0.5 \mathrm{~g}$, yeast extract $0.5 \mathrm{~g}$, peptone $0.5 \mathrm{~g}, \mathrm{KH}_{2} \mathrm{PO}_{4} 0.1 \mathrm{~g}$, $\mathrm{MgSO}_{4.7} \mathrm{H}_{2} \mathrm{O} \quad 0.02 \mathrm{~g}$, Congo red $0.015 \mathrm{~g}$, $\mathrm{Ca}_{2} \mathrm{CO}_{3} 0.01 \mathrm{~g}$, Agar $2 \mathrm{~g}$ The media was autoclaved at $121^{\circ} \mathrm{C}$ and 15 pound/inch ${ }^{2}$ for 15 min.

\section{Isolation of Bacillus species}

Each soil sample (20g) was suspended in sterile distilled water in a steril bottle(total volume of $20 \mathrm{ml}$, vortexed and placed in water bath at $100{ }^{\circ} \mathrm{C}$ for 5 min with shaking. Heat treated soil suspensions were incubated at room temperature for $2 \mathrm{~h}$ and serially diluted from $10^{-1}$ to $10^{-7}$, $1 \mathrm{ml}$ from each dilute was transferred to petri dish followed by adding above mentioned media. All petri dishes were incubated at $35^{\circ} \mathrm{C}$ for $48 \mathrm{~h}$. The transferring process was repeated for several times for colonies which have clear zone to get pure isolates.

\section{Identification of Bacillus isolates}

Study of cultural and morphological

\section{characteristics of Bacterial isolates}

The cultural characteristics of bacterial isolates on NA media and morphological

characteristics, was carried out by using Gram and malachite stains according to method of

(7). The shape of bacterial cells and the presence of spores were examid under microscopic field.

\section{Catalase test}

Small amount of maintend colonies was transferred to the surface of a clean dry glass slide, a drop of $3 \% \mathrm{H}_{2} \mathrm{O}_{2}$ was placed on the top of colonies for testing oxygen bubbles formation (7).

\section{Quantitative screening \\ Production media}

The media was used for quantitative screening was prepared according (5) contained Xylan $0.5 \mathrm{~g}$ ، Peptone $0.5 \mathrm{~g}$ ، $\mathrm{NaCl} 0.1 \mathrm{~g} \cdot \mathrm{K}_{2} \mathrm{HPO}_{4} 0.2 \mathrm{~g}$ ، $\mathrm{CaCl}_{2} \quad 0.01 \mathrm{~g} \cdot \mathrm{MgSO}_{4.7} \mathrm{H}_{2} \mathrm{O} 0.01 \mathrm{~g}$ ، and Yeast extract $0.1 \mathrm{~g}$ were dissolved in $100 \mathrm{ml}$ distilled water, and $\mathrm{pH}$ was adjusted to 7 . Media was autoclaved and used for screening xylanase production isolates.

\section{Screening the isolates for xylanase production}

Production media was placed in to $250 \mathrm{ml}$ Erlenmeyer flask, autoclaved at $121 \mathrm{c}^{\circ}$ for 15 min, Flasks were inoculated with $1 \mathrm{ml}$ cell suspension at adensity of $10^{7}$ cell $/ \mathrm{ml}$ media.The fermentation was carried out in ashaking incubater at aspeed of $150 \mathrm{rpm}$ at 37 $\mathrm{c}^{\circ}$ for $48 \mathrm{hr}$ (5). After the fermentation process was finished, the supernatant was separated by centerfuge at aspeed $12000 \mathrm{rpm}$ for $10 \mathrm{~min}$ at $4 c^{\circ}$ (13). The supernatant was used as the source of crude enzyme for xylanase assay.

\section{Enzyme activity assay}

Crude xylanase activity was assay in supernatant according to (10). The reaction mixture contained $0.9 \mathrm{~mL}$ substrate (prepared by dissolve $1 \mathrm{~g}$ xylan in $100 \mathrm{ml}$ phosphate buffer, $50 \mathrm{mM}, \mathrm{pH} 7), 0.1 \mathrm{~mL}$ of enzyme sample. The assay mixture was incubated at 50 ${ }^{\circ} \mathrm{C} / 5 \mathrm{~min}$. one $\mathrm{mL} \mathrm{DNS}$ reagent was added to the reaction mixture, boiled for $5 \mathrm{~min}$. Then, 
the mixture cooled down. The absorbant read by spectrophotometer at a wavelength of 540 nm. The amount of xylose produced by enzymes function was determined using xylose standard curve. One unit of xylanase enzyme was defined as the amount enzyme required to release $1 \mu \mathrm{m}$ of xylose per minute in under assay condition.

\section{Molecular identification}

DNA Extraction: The local Bacillus sp. isolate (RS1) was cultured on $\mathrm{NB}$ at $37^{\circ} \mathrm{C}$ on rotary shaker at $150 \mathrm{rpm}$ for $24 \mathrm{hr} .3 \mathrm{ml}$ of the broth media culture was centrifuged at 13000 $\mathrm{x} \mathrm{g}$ for $1 \mathrm{~min}$. (the supernatant was discarded). $100-500 \mathrm{mg}$ of precipitated biomass cells was

Table 1. The sequence of used primers

\begin{tabular}{|lc|}
\hline Primer & Sequence \\
\hline Forward & 5'-CGGGTGAGTAACACGTG-3' \\
Reverse & 5'-CGGTGTGTACAAGCCC-3' \\
\hline
\end{tabular}

taken and smashed under liquid nitrogen by using a mortar. The smashed sample was transferred to a $1.5 \mathrm{ml}$ Eppendorf tube. A molecular biology kit (from Presto Mini g DNA Bacteria Kit, Tiwan) was used to extract the DNA from the isolate according to the kit extraction method. DNA purification was estimated by Nano drop

Polymerase chain reaction (PCR)

Table 3. The components of the PCR master mixture

\begin{tabular}{|llccc|}
\hline No. & \multicolumn{1}{c}{ Step } & Temperature & Time & Cycles \\
\hline 1 & Initial Denaturation & $\mathbf{9 4}^{\circ} \mathrm{C}$ & $\mathbf{4 ~ m i n}$. & One cycle \\
2 & Denaturation & $\mathbf{9 4}^{\circ} \mathrm{C}$ & $\mathbf{4 0 ~ s e c .}$ & \\
3 & Annealing & $\mathbf{5 3}^{\circ} \mathrm{C}$ & $\mathbf{5 0 ~ s e c .}$ & \\
4 & Elongation-1 & $\mathbf{7 2}^{\circ} \mathrm{C}$ & $\mathbf{8 0 ~ s e c .}$ & 35 cycle \\
5 & Elongation -2 & ${72^{\circ} \mathrm{C}}^{\circ}$ & $\mathbf{8 ~ m i n .}$ & One cycle \\
6 & Holding & $4^{\circ} \mathrm{C}$ & $\infty$ & \\
\hline
\end{tabular}

The Electrophoresis of DNA amplification products on agarose gel

The PCR products were loaded on $1.5 \%$ agarose gel using a horizontal electrophoresis. $5 \mu \mathrm{l}$ of PCR products and $2 \mu \mathrm{l}$ of loading buffer for every each $5 \mu 1$ of DNA extract. The mixture was mixed well and located into the sample gel wells. The sample was subjected to electrophoresis assay for 1 hour, 5 voltlcm and 70 milliamps in order to initiate the movement toward negative and positive poles. The DNA bands were detected by using UV light Tran's illuminator device.

Determination of nitrogen bases sequence

The gene amplifying products have been sent to Korean Macrogen Company in order to determine the nitrogen bases (DNA sequencing) for the pure isolate. The
PCR was used to amplify the $16 \mathrm{~S}$ rRNA of the rRNA gene. The forward primer 5'CGGGTGAGTAACACGTG-3' and reverse primer 5'-CGGTGTGTACAAGCCC-3' were used in PCR table (1) (14). The concentration of the primer was 10 pecomole and the numbers of nitrogen bases were 17 in forward and reverse primer. The amplification was done in $20 \mu \mathrm{l}$ which then added to the master mix that was supplied by the Bioneer Company Table (2).

Table 2. Master mix amplification compounds

\begin{tabular}{|lc|}
\hline Compounds in the master mix & Vol. $(\mu \mathrm{l})$ \\
\hline 10 picomole Forward primer & 2 \\
10 picomole Reverse primer & 2 \\
DNA extract & 4 \\
Deionized water & 12 \\
Total volume & 20 \\
\hline
\end{tabular}

The master mixture was mixed for few seconds using vortex. The tube was placed in PCR thermo cycler. The device was programmed according to table (3) and the amplification was taken place to amplify the extracted DNA. By the end of the reaction time, $5 \mu \mathrm{l}$ of $16 \mathrm{~S}$ rRNA amplifying product was withdrawn for electrophoresis assy. sequencing was compared with the available information on that gene with NCBI website using BLAST Nucleotides software to identify the species of the chosen isolates.

\section{xylanase Production from agricultures waste \\ Xylan extraction}

Xylan was prepared from three different agriculture wastes by dilute acid according to (20), wheat stalks,sun flower stalks and papyrus were soaked in sulfuric acid diluted $(0.01 \mathrm{M})$ for $12 \mathrm{hr}$ at $60 \mathrm{C}^{\circ}$, , the biomass was collected, washed with distilled water until $\mathrm{pH} 7$ and oven-drying. Biomass was mixed with water $(1: 3 \mathrm{w} / \mathrm{v})$ then autoclaved at $121 \mathrm{C}^{\circ}$ for $60 \mathrm{~min}$. Biomass was drided and grinded for xylan getting.

Quantification of extracted xylan 
Extracted xylan was determined by $\mathrm{H}_{2} \mathrm{SO}_{4}$ Phenol method as describe by (3). The absorbance was measured at $490 \mathrm{~nm}$ by using the xylose standard curve.

\section{RESULTS AND DISCUSSION}

\section{Isolation of Bacteria}

Seventeen local bacterial isolates were obtained from soil samples, have been survived heat treatments at $100 c^{\circ}$ for 5 min and that was due to their spore's resistance to high temperature (4),(15). All isolates tested under the microscope were Gram-positive, rodshaped and contains oval endospores at inside the cell when they stained by Malachite green stain. Colonies are spreading and irregularly- shaped and Catalase- positive The (Fig.1) shows all isolates were able to form clear zone around their grown colonies on isolation which contain congo red dye. Formation of clear zones by isolates as indication of xylanase production. Obtaind isolates were identified as Bacillus according to the cultural and morphological characteristics table (4). Jernejc (8) reported that the isolation process for any microorganism need to known the most important characteristic which represents the main target of this process. Generally, the desired characteristic is a restricted factor to isolate the microorganism from its natural media (soil, water, air, etc).

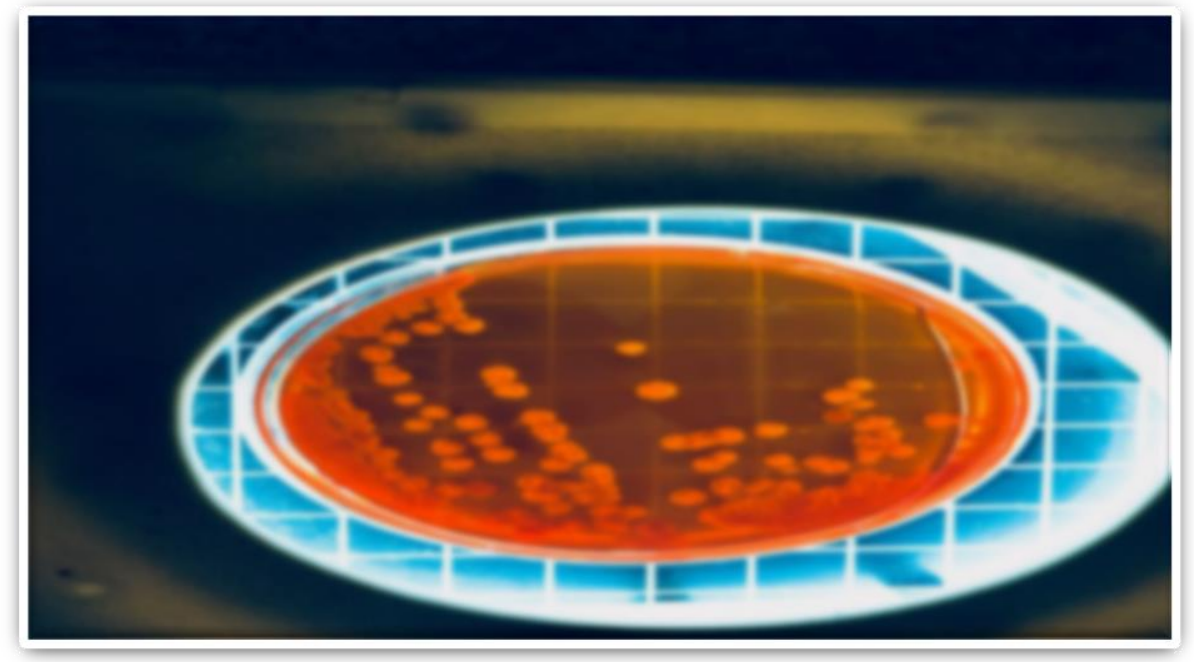

Fig. 1. clear zone on isolate media which contain congo red dye

Table 4. The most important cultural and morphological characteristics of the local Bacillus sp. Isolates

\begin{tabular}{|ll|}
\hline Characteristic & \multicolumn{1}{c|}{ Observations } \\
\hline $\begin{array}{l}\text { Growth on the solid } \\
\text { medium }\end{array}$ & Fairly regular and widespread with a smooth surface \\
Colonical color & Opaque \\
Colonial edges & Circular with irregular or cut edges \\
Shap of cells & Long rod,straight or slightly curved \\
Response for gram's & Positive for gram's stain \\
stain & Central or sub-central spores \\
Spores forming & Elliptical \\
Spore shape & \\
\hline
\end{tabular}

\section{Screening of Bacillus isolates}

The seventeen isolates were subjected to the quantitative screening. Despite that the isolates varied capabilities to produce the xylanase enzyme, isolate Bacillus sp.RS1was the most distinguished one among others by giving enzymatic activity with value reached 2680 unit/ml (Fig.2), this isolate was selected to be used in the experiments of this research study.
Several studies have been conducted about bacteria producing xylanase, Yasinok (21) reported that Bacillus pumilus M1and Bacillus pumilus M2 which were isolated from zea mays, had ability to give enzymatic activity (188.0 and 5.6) U/ml repectivly. Chaturvedi (2) have found that Bacillus licheniformis had high ability to give enzymatic activity as compared with 18 isolates of Bacillus which were isolated from decomposed wood. 


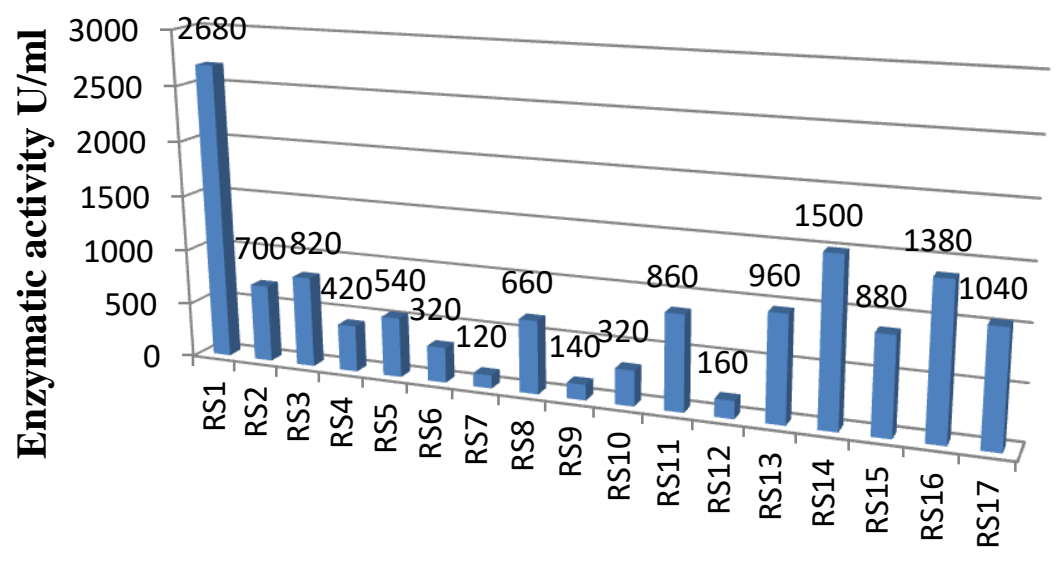

Bacterial isolates

Fig. 2. A screening for 17 Bacillus isolates in production media depending on the total xylanase activity

\section{Molecular Identification}

DNA extraction: The DNA was extracted from Bacillus sp. RS1 and the purity of DNA was examined by Nano Drop with a purity of 1.95 which is adequate for Polymerase Chain Reaction (PCR) process. Green (6) reported that the PCR did not need a large quantity of DNA which may instead produce unlimited amplifying products. On other hand, an adequate quantity of DNA may reduce the accuracy.

\section{Polymerase Chain Reaction (PCR)}

A PCR for the local Bacillus sp. RS1 for $16 \mathrm{~S}$ rRNA gene was carried out. The electrophoresis on $1.5 \%$ agarose show (by using U.V detector), that there was a clear band represents the genes amplifications (Fig.3). The molecular size of gene amplification band was between 1000-1500 bp comparing with ladder size at the same conditions, which refers to the prime binding to the complete sequence in DNA pattern.

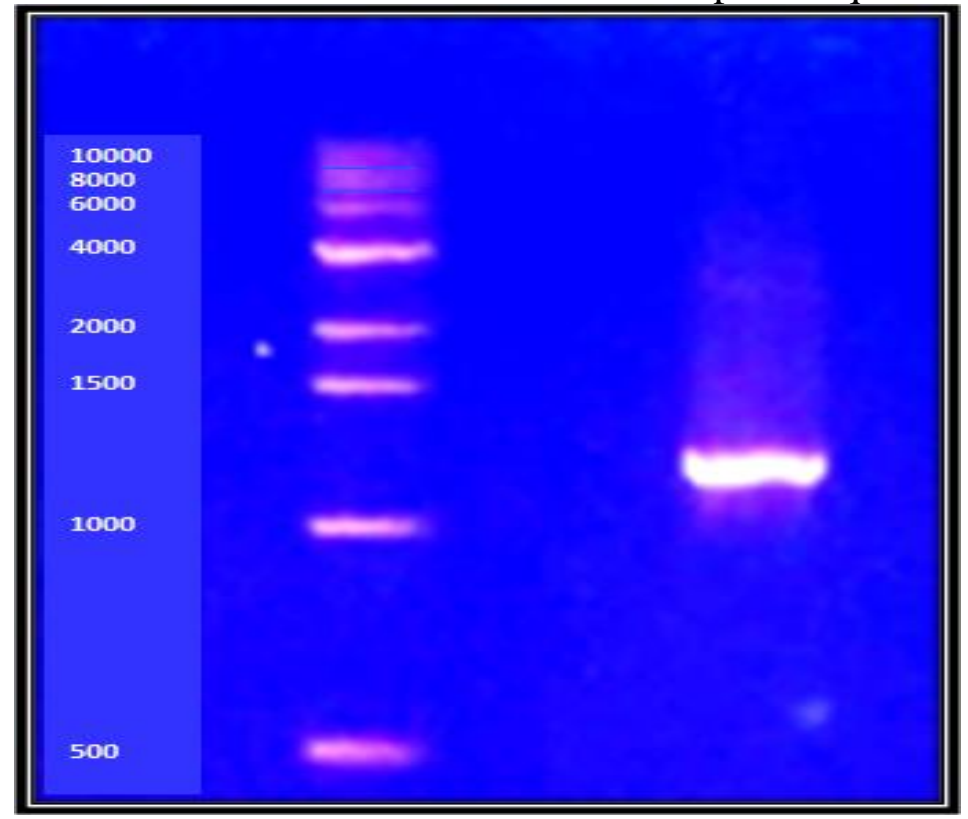

Fig. 3. Electrophoresis for the local

Bacillus sp. RS1 for 16S rRNA gene on agarose gel.

Sequence analysis of amplification products

The sequence of nitrogen bases, of the $16 \mathrm{~S}$ rRNA gene, for the local mold isolate (Bacillus sp. RS1) was studied by sending the amplification products to the Korean company
Macrogen (Fig.4). The nitrogen bases sequence (1429 base-pair) which was taken from the local isolate sequence (of the present study) is shown in (Fig.5). The PLAST program has been used to find out the 
similarity of gene with the bank information (NCBI). The results showed that there is a match between isolation and $99 \%$ with global isolation sequences global ID: MG027675.1
Registered on the NCBI website and registered in the United States of America Which belong to Bacillus subtilus strain VBN25. (Fig.6).

\begin{tabular}{l}
\hline \\
GGGAACCGGGGCTAATACCGGATGGTTGTTTGAACCGCATGGTTCAAACATAAAAGGTGGCTTCGG \\
CTACCACTTACAGATGGACCCGCGGCGCATTAGCTAGTTGGTGAGGTAATGGCTCACCAAGGCAAC \\
GATGCGTAGCCGACCTGAGAGGGTGATCGGCCACACTGGGACTGAGACACGGCCCAGACTCCTAC \\
GGGAGGCAGCAGTAGGGAATCTCCGCAATGGACGAAGTCTGACGGAGCAACGCCGCGTGAGTG \\
ATGAAGGTTTTCGGATCGTAAAGCTCTGTTGTTAGGGAAGAACAAGTACCGTTCGAATAGGGCGGT \\
ACCTTGACGGTACCTAACCAGAAAGCCACGGCTAACTACGTGCCAGCAGCCGCGGTAATACGTAGG \\
TGGCAAGCGTTGTCCGGAATTATTGGGCGTAAAGGGCTCGCAGGCGGTTTCTTAAGTCTGATGTGA \\
AAGCCCCCGGCTCAACCGGGGAGGGTCATTGGAAACTGGGGAACTTGAGTGCAGAAGAGGAGAGT \\
GGAATTCCACGTGTAGCGGTGAAATGCGTAGAGATGTGGAGGAACACCAGTGGCGAAGGCGACTC \\
TCTGGTCTGTAACTGACGCTGAGGAGCGAAAGCGTGGGGAGCGAACAGGATTAGATACCCTGGTA \\
GTCCACGCCGTAAACGATGAGTGCTAAGTGTTAGGGGGTTTCCGCCCCTTAGTGCTGCAGCTAACG \\
CATTAAGCACTCCGCCTGGGGAGTACGGTCGCAAGACTGAAACTCAAAGGAATTGACGGGGGCCC \\
GCACAAGCGGTGGAGCATGTGGTTTAATTCGAAGCAACGCGAAGAACCTTACCAGGTCTTGACATC \\
CTCTGACAATCCTAGAGATAGGACGTCCCCTTCGGGGGCAGAGTGACAGGTGGTGCATGGTTGTCG \\
TCAGCTCGTGTCGTGAGATGTTGGGTAAGTCCCGCAACGAGCGCAACCCTTGATCTTAGTTGCCA \\
GCATTCAGTTGGGCACTCTAAGGTGACTGGCCGGTGACAAACCGGAAGAAAGGTGGGGGATGAAC \\
GTCAAATCATCATGCCCCC
\end{tabular}

Fig. 4. Sequence for the local Bacillus sp. RS1 for the 16S rRNA

Bacillus subulis strain VBN25 16 S nbosomal RNA gene, partial sequence

Sequence ID: MG027675.1 Length: 1427 Number of Matches: 1

Related Inform ation

Range 1: 77 to 1141 Gen Bank Gnphics Net Match Frrsious Mateh

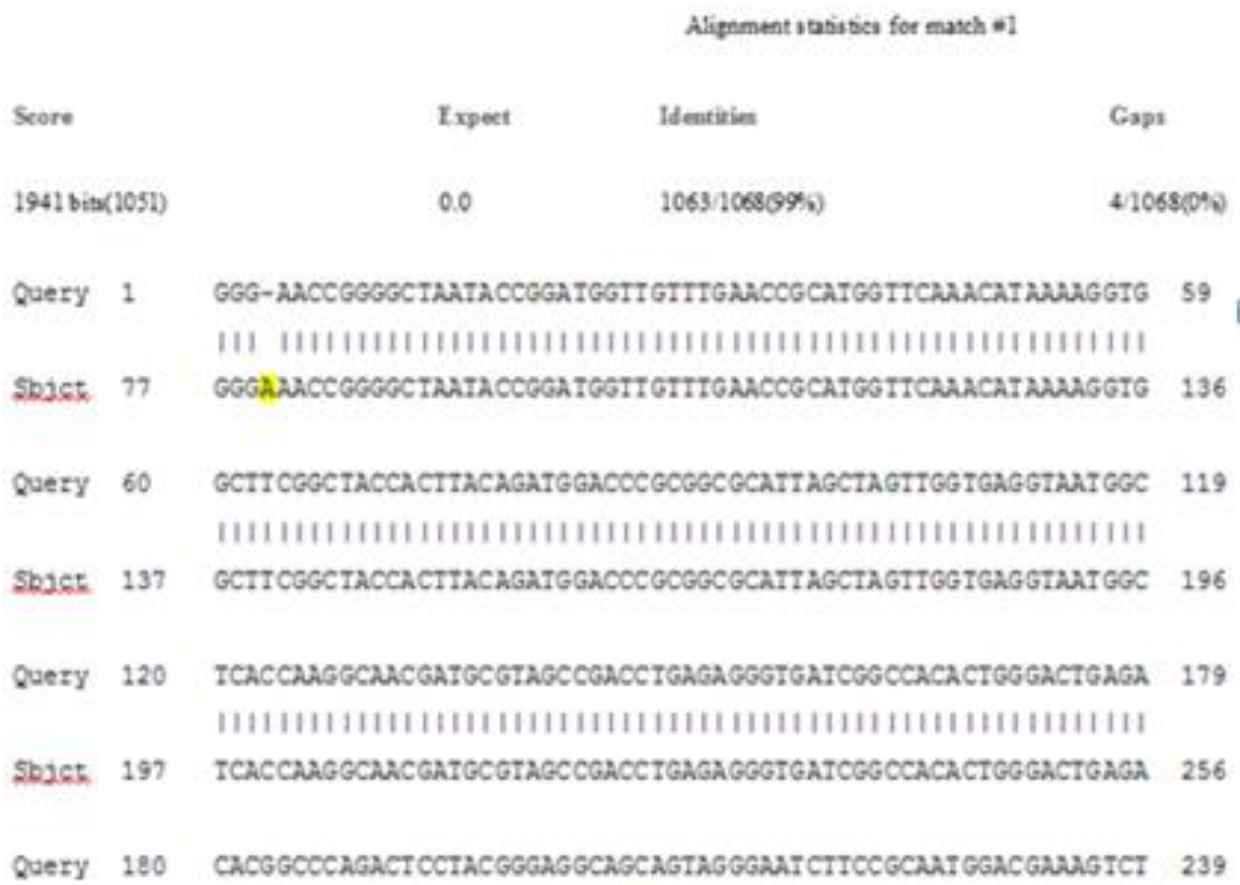

Fig. 5. Match the sequence of nitrogen bases for 16S rRNA for the local Bacillus sp.RS1 with global isolate Bacillus subtilus strain VBN25

Shows phylogenetic tree for the local isolate with the other strain in NCBI, the results shows clear convergence between a local isolate Bacillus subtilus RS1 and standerd strains in genes bank NCBI 


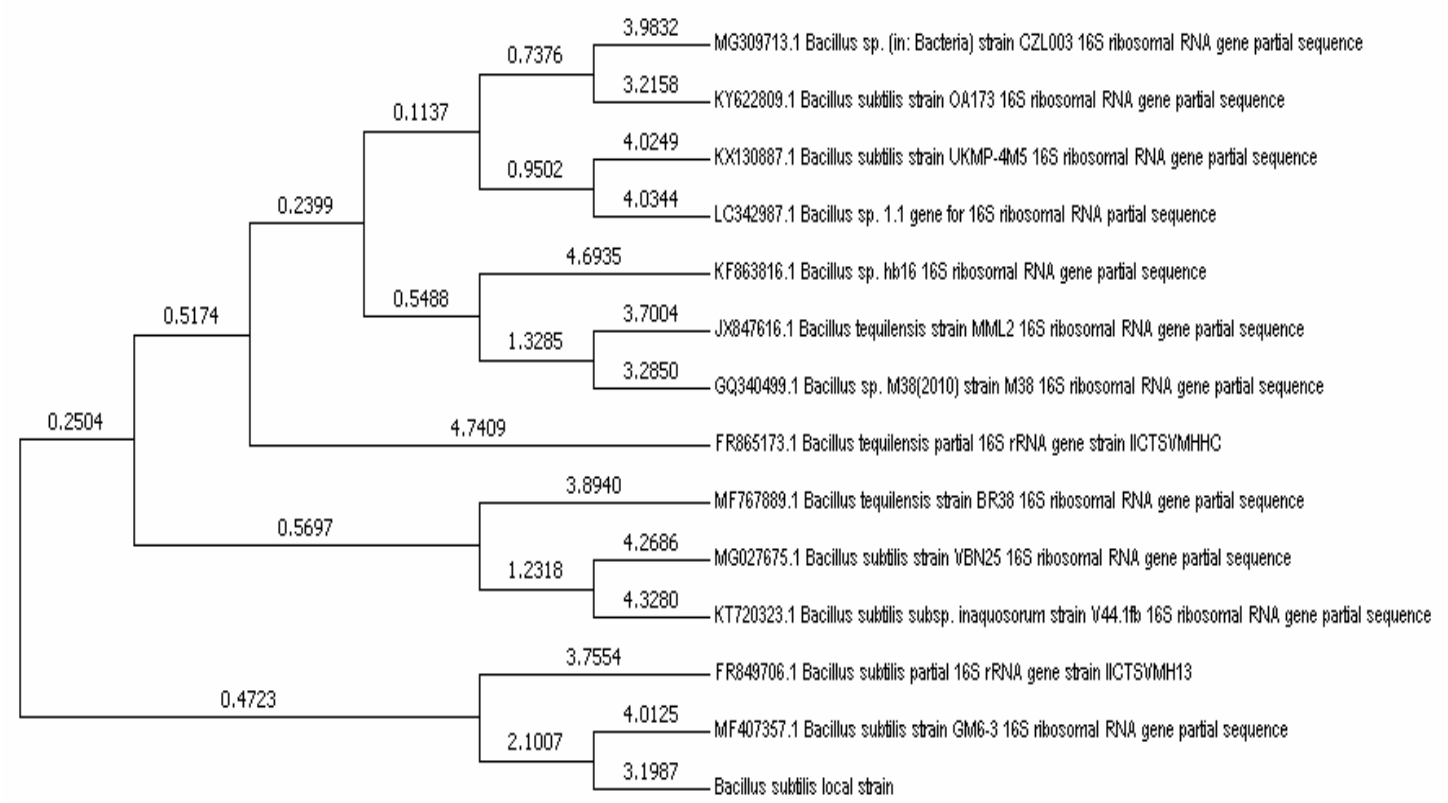

Fig. 6. phylogenetic tree for the local isolate with the other strain in genes bank NCBI Quantification of extracted xylan

Table (5) has shown that the papyrus gave the highest amount of xylan $(187.6 \mu \mathrm{g} / \mathrm{ml})$ as compared with that of the sun flower stalks, Ibaa Wheat type, Furat wheat type and Abo Ghraib wheat type(161.3, 161.6, 157.6, 157.2) $\mu \mathrm{g} / \mathrm{ml}$ respectively.
Production of xylanase from agricultural wastes by Bacillus subtilus

Fig (7 ) shows the results of the enzymatic activity for the product xylinase by Bacillus subtilus by using extracted xylan from different agriculture waste. The results

Table 5. Quantity of xylan in variety agricultur waste

\begin{tabular}{|r|}
\hline Quantity of xylan \\
\hline 157.6 \\
157.2 \\
161.6 \\
187.6 \\
161.3
\end{tabular}

indicated that the highest activity was 2800 $\mathrm{u} / \mathrm{ml}$ produced by Bacillus subtilus when used Papyrus xylan, and the enzymatic activity by using Ibaa Wheat type, sun flower stalks ,

\section{Agricultur waste}

\section{Furat wheat type \\ Abo Ghraib wheat type \\ Ibaa Wheat type \\ Papyrus \\ sun flower stalks}

wheat

Furat wheat type and Abo Ghraib wheat type were( 2411،2407،2352،2346) u/ml

respectivily, these results could be attributed to the difference in xylan soures. 


\section{REFRENCES}

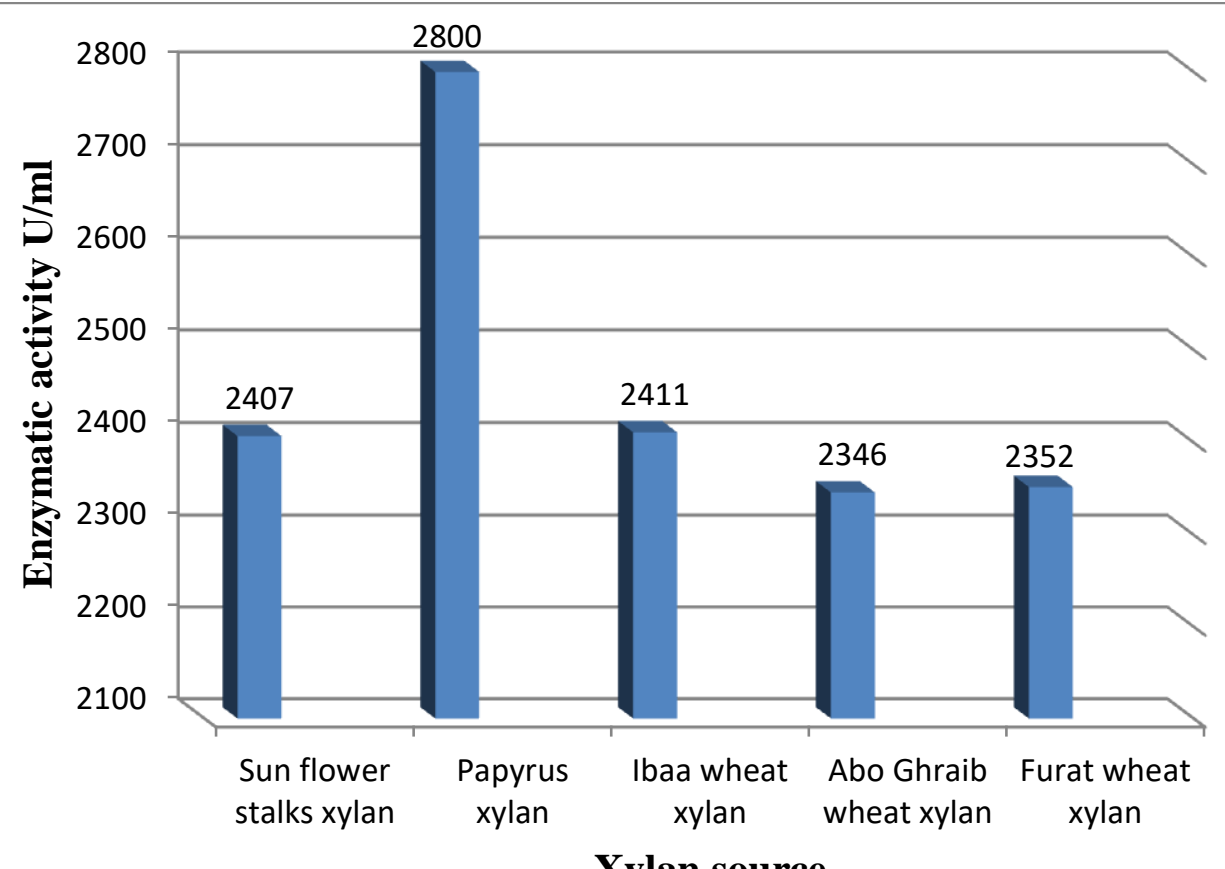

Xylan source

Fig. 7.Effect of xylan soures in xylanase production by Bacillus subtilus
1.Acharya, K. P. and P. Shilpkar. 2016. Production, partial purification and characterization of xylanase using Nicotiana tabacum leaf dust as substrate. Journal of environmental biology, 37(2), 297.

2.Chaturvedi, S.; R. Singh, and P. Khurana. 2013. Isolation and Identification of xylanolytic enzyme from an effective strain Bacillus licheniformis isolated from the decaying wood. International Journal of Applied Biology and Pharmaceutical Technology, 4(4): 92-100

3.Dubois, M.; K. A. Gilles,; J. K. Hamilton,; P. A. Robers, and F. F. Smith, 1956. Colorimetric method for determination of sugars and related substances. Analytical Chemistry, 28: 350356.

4.Earl, A. M.; R. Losick, and R. Kolter. 2008. Ecology and genomics of Bacillus subtilis. Trends in microbiology, 16(6), 269275

5.Gowdhaman, D.; G. Jeyalakshmi,; K. Sugumaran,; N. S. Subramanian,; R. S. Santhosh. and V. Ponnusami. 2014. Optimization of the xylanase production with the newly isolated Bacillus aerophilus KGJ2. Turkish Journal of Biochemistry, 39(1): 70-77 6.Green, M. R. and J. Sambrook. 2012. Molecular cloning: a laboratory manual: threevolume set. Cold Spring Harbor Laboratory Press.
7.Harrigan, F. W. and M. E. McCance. 1976. Laboratory Methods in Microbiology. Acadamic Press of London, New York, pp: 27 8.Jernejc, K. and A. Cimerman. 2001. Morphological characteristics, extracellular and intracellular protein and enzyme patterns of five Aspergillus species. Food Technology and Biotechnology, 39(4), 333-340.

9.Khusro, A.; B. K. Kaliyan,; N. A. Al-Dhabi,; M. V. Arasu, and P. Agastian. 2016. Statistical optimization of thermo-alkali stable xylanase production from Bacillus tequilensis strain ARMATI. Electronic Journal of Biotechnology, 22, 16-25

10.Miller, G. L. 1959. Use of dinitrosalicylic acid reagent for determination of reducing suger. Analytical Chemistry, 31(3): 426-429

11.Moteshafi, H.; S. M. Mousavi, and M. Hashemi. 2016. Enhancement of xylanase productivity using industrial by-products under solid suspended fermentation in a stirred tank bioreactor, with a dissolved oxygen constant control strategy. RSC Advances, 6(42), 3555935567

12.Pithadiya, D.; D. Nandha, and A. Thakkar. 2016. Partial purification and optimization of xylanase from Bacillus circulans. Archives of Applied Science Research, 8(2); 1-10

13,Roy, N. and H. M. Rawshanul. 2009. Isolation and characterization of Xylanase 
producing strain of Bacillus cereus from soil. Iranian Journal of Microbiology, (2): 49-53

14.Sacchi, C. T.; A. M. Whitney,; L. W. Mayer,; R. Morey,; A. Steigerwalt,; A. Boras,; Weyant,; S. Robin, and P. Tanja. 2002. Sequencing of $16 \mathrm{~S}$ rRNA Gene A rapid Tool for Identification of Bacillus anrhracis. Emerging Infectious Diseases Journal, 8(10): 1117-1123

15.Sadfi, N.; M. Cherif,; I. Fliss,; A. Boudabbous, and H. Antoun. 2001. Evaluation of bacterial isolates from salty soils and Bacillus thuringiensis strains for the biocontrol of Fusarium dry rot of potato tubers. Journal of Plant Pathology, 101-117

16.Sarika, C.; R. Singh, and S. M. Paul Khurana. 2013. Isolation and identification of xylanolytic enzyme from an effective strain Bacillus licheniformis isolated from the decaying wood. International Journal of Applied Biology and Pharmaceutical Technology, 4,4
17.Seo, J. K.; T. S. Park,; I. H. Kwon,; M. Y. Piao,; C. H. Lee, and J. K. Ha. 2013. Characterization of Cellulolytic and Xylanolytic Enzymes of Baillus licheniformis JK7 Isolated from the Ruman of a Native Korean Goat. Asian-Australasian Journal of Animal Sciences, 26(1); 50-58

18.Suto, M. M.; K. Takebayashi,; M. Saito,; A. Tanaka,; A. Yokota, and F. Tomita. 2002. Endophytes as producer of xylanase. J. Biosci. Bioeng. 93: 88-90

19.Vijayalakshmi, S.; J. Ranjitha, and V. D. Rajeswari. 2013. Enzyme production ability by Bacillus subtilis and Bacillus licheniformis A comparative study. Asian Journal Pharmaceutical and Clinical Research, 6(4), 29-32

20.Yang, R.; S. Xu,; Z. Wang, And W. Yang. 2005. Aqueous extraction of corncob xylan and production of xyloolgosaccharides. LWTFood Sci Technol, 38:677-682.

21.Yasinok, A. E.; F. L. Sahin, and M. Haberal. 2008. Isolation of Endopfytic and Xylanolytic Bacillus pumilus Strain from Zea mays. Tarim Bilimleri Dergisi, 14(4): 374:380. 